\title{
Commentary NICE-SUGAR: the end of a sweet dream?
} Jean-Charles Preiser

Department of Intensive Care, Centre Hospitalier Universitaire du Sart Tilman, 4000 Liege, Belgium.

Corresponding author: Jean-Charles Preiser, Jean-Charles.Preiser@chu.ulg.ac.be

Published: 14 May 2009

This article is online at http://ccforum.com/content/13/3/143

(c) 2009 BioMed Central Ltd
Critical Care 2009, 13:143 (doi:10.1186/cc7790)

concluded simply that tight glucose control is not associated with significantly reduced hospital mortality. Criticisms of each of the individual studies were raised, including inadequate statistical power and the use of various degrees of glucose control, all lower in the subsequent trials [3-7] than in the initial Leuven I study [2]. Therefore, the NICE-SUGAR trial was eagerly awaited by the intensive care medicine community worldwide.

The sample size of NICE-SUGAR was calculated to detect a $3.8 \%$ absolute difference in mortality (treatment effect reported in the Leuven I trial) with a power of $90 \%$, assuming a baseline mortality of 30\% [2]. NICE-SUGAR was conducted in a network of intensive care units that had previously collaborated and included patients in large-scale trials. A web-based electronic algorithm was used to adapt the insulin infusion rate. Under these conditions (optimal for successful performance of a multicentre trial) the primary outcome variable, namely 90-day mortality, was found to be increased from $24.9 \%$ in the conventional/control group arm to $27.5 \%$ in the intensive treatment arm, which is in complete contrast to the findings of the Leuven I trial. These findings allow us to address certain issues and provide some answers, but they also raise new questions.

The main issue considered by NICE-SUGAR - whether the Leuven I trial has external validity - is clearly addressed in the negative, in contrast to previous hopes and beliefs. Possible reasons for the lack of external validity are multiple and include major differences in the amount of intravenous glucose infused, the frequency of use of enteral nutrition and possibly a lower 'commitment' to TGCIIT by centres other than Leuven. Nonetheless, NICE-SUGAR probably succeeded in separating the levels of glycaemia reached in the two experimental groups, even though the interquartile ranges of the values are not stated in the report [2]. Whatever the reason for the disparity between the results of the Leuven I

NICE-SUGAR = Normoglycaemia in Intensive Care Evaluation Survival Using Glucose Algorithm Regulation; TGCIIT = tight glucose control by intensive insulin therapy. 


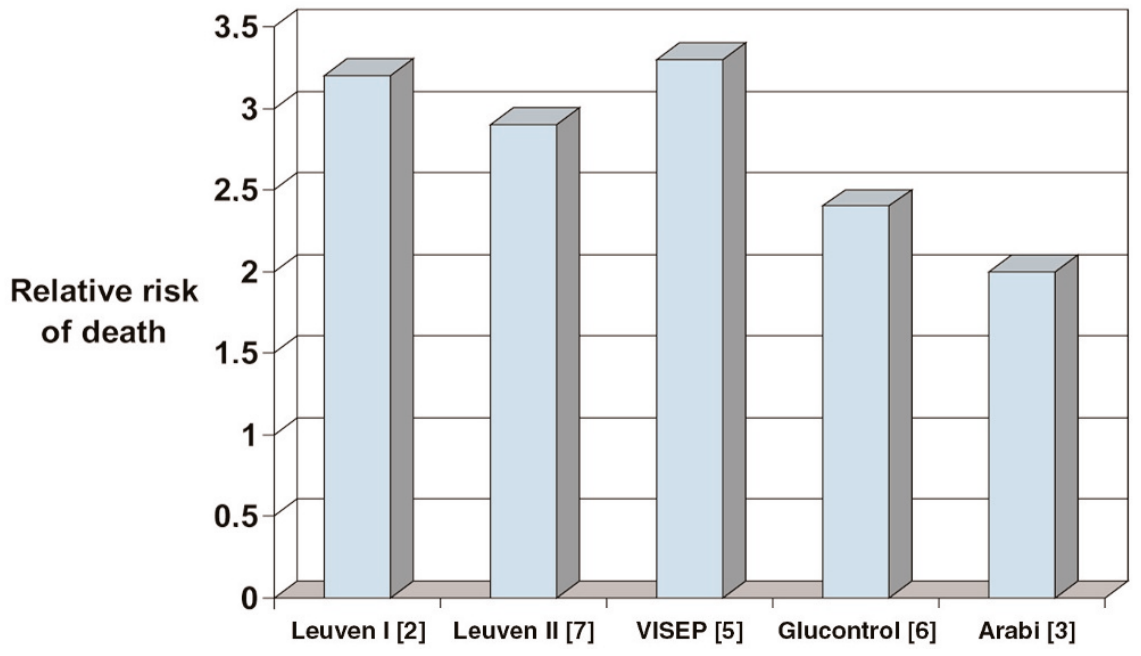

Relative risk for death in patients with hypoglycaemia. Shown are the relative mortality rates in patients included in prospective studies of tight glucose control by intensive insulin therapy who experienced hypoglycaemia versus those who did not. Mortality rate was increased by a factor of 2 to 3.3 among patients who experienced hypoglycaemia.

trial and other studies, some standards of care will be changed. The Endocrine Society has already issued a statement [10], just after the publication of the results of NICE-SUGAR, advocating the need for more nuanced recommendations on glucose control. Likewise, other official bodies (for instance, the Joint Commission on Accreditation of Healthcare Organizations, the Institute for Healthcare Improvement and the Volunteer Hospital Organization) that issued recommendations on tight glucose control in critically ill patients will need to re-consider their position.

The new questions raised by NICE-SUGAR probably include the actual validity of the concept of 80 to $110 \mathrm{mg} / \mathrm{dl}$ (4.4 to $6.1 \mathrm{mmol} / \mathrm{l})$ as 'normoglycaemia' or even desirable glycaemia during critical illness [11]. Another key but unresolved and poorly investigated issue is the possible nonglycaemic effects of insulin in the late divergence in the cumulative survival curves observed both in the Leuven studies [2,7] and in NICE-SUGAR [1], albeit in opposite directions. Other pending questions raised include the risks and potentially harmful effects of high variability in glucose levels, which are probably influenced by TGCIIT [12-14]. Finally, the absence of risks for hypoglycaemia, although not studied specifically in NICE-SUGAR, is questionable when the mortality rate of patients who experienced hypoglycaemia was systematically two to three times higher than in nonhypoglycaemic patients (Figure 1). The effects of hypoglycaemia can be particularly harmful in brain-injured patients $[15,16]$.

With these uncertainties in mind, the only target for blood glucose that can currently be recommended will probably be in the intermediate range, even in the absence of direct evidence. An intermediate level will probably allow safer although effective glucose control [17].

\section{Competing interests}

The author declares that they have no competing interests.

\section{References}

1. NICE-SUGAR Study Investigators, Finfer S, Chittock DR, Su SY, Blair D, Foster D, Dhingra V, Bellomo R, Cook D, Dodek P, Henderson WR, Hebert PC, Heritier S, Heyland DK, McArthur C, McDonald E, Mitchell I, Myburgh JA, Norton R, Potter J, Robinson $\mathrm{BG}$, Ronco JJ: Intensive versus conventional glucose control in critically ill patients. N Engl J Med 2009, 360:1346-1349.

2. Van den Berghe G, Wouters P, Weekers F, Verwaest C, Bruyninckx F, Schetz M, Vlasselaers D, Ferdinande P, Lauwers P, Bouillon R: Intensive insulin therapy in the critically ill patients. $N$ Engl J Med 2001, 345:1359-67.

3. Arabi YM, Dabbagh OC, Tamim HM, Al-Shimemeri AA, Memish ZA, Haddad SH, Sved SJ, Giridhar HR, Rishu AH, Al-Daker MO, Kahoul SH, Britts RJ, Sakkijha MH: Intensive versus conventional insulin therapy: a randomized controlled trial in medical and surgical critically ill patients. Crit Care Med 2008, 36: 3190-3197.

4. De La Rosa GD, Donado JH, Restrepo AH, Quintero AM, Gonzalez LG, Saldarriaga NE, Bedoya M, Toro JM, Velasquez JB, Valencia $\mathrm{JC}$, Arango CM, Aleman PH, Vasquez EM, Chavarriaga JC, Yepes A, Pulido W, Cadavid CA, Grupo de Investigacion en Cuidado intensivo: GICl-HPTU: Strict glycaemic control in patients hospitalised in a mixed medical and surgical intensive care unit: a randomised clinical trial. Crit Care 2008, 12:R120.

5. Brunkhorst FM, Engel C, Bloos F, Meier-Hellmann A, Ragaller M, Weiler N, Moerer O, Gruendling M, Oppert M, Grond S, Olthoff D, Jaschinski U, John S, Rossaint R, Welte T, Schaefer M, Kern P, Kuhnt E, Kiehntopf M, Hartoq C, Natanson C, Loeffler M, Reinhart K, German Competence Network Sepsis (SepNet): Intensive insulin therapy and pentastarch resuscitation in severe sepsis. N Engl J Med 2008, 358:125-139.

6. Devos P, Preiser JC, Melot C: Impact of tight glucose control by intensive insulin therapy on ICU mortality and the rate of hypoglycaemia: final results of the Glucontrol study. Intensive Care Med 2007, 33:S189. 
7. Van den Berghe G, Wilmer A, Hermans G, Meersseman W, Wouters PJ, Milants I, Van Wijngaerden E, Bobbaers H, Bouillon $\mathrm{R}$ : Intensive insulin therapy in the medical ICU. N Engl J Med 2006, 354:449-461.

8. Wiener RS, Wiener DC, Larson RJ: Benefits and risks of tight glucose control in critically ill adults: a meta-analysis. JAMA 2008, 300:933-944.

9. Griesdale DEG, de Souza RJ, van Dam RM, Heyland DK, Cook DJ, Malhotra A, Dhaliwal R, Henderson WR, Chittock DR, Finfer S, Talmor D: Intensive insulin therapy and mortality among critically ill patients: a meta-analysis including NICE-SUGAR study data. CMAJ 2009, 180:821-827.

10. The Endocrine Society Statement to Providers on the Report Published in the New England Journal of Medicine on NICESUGAR [http://www.endo-society.org/advocacy/legislative/letters/ upload/NICE-SUGAR-Position-Statement-FINAL.pdf]

11. Preiser JC: Restoring normoglycaemia: not so harmless. Crit Care 2008, 12:116.

12. Ali NA, O'Brien JM Jr, Dungan K, Phillips G, Marsh CB, Lemeshow S, Connors AF Jr, Preiser JC: Glucose variability is independently associated with increased mortality in patients with severe sepsis. Crit Care Med 2008, 36:2316-2321.

13. Egi M, Bellomo R, Reade MC: Is reducing variability of blood glucose the real but hidden target of intensive insulin therapy? Crit Care 2009:in press.

14. Ali NA, Krinsley JS, Preiser JC. Glucose variability in critically ill patients. In The Yearbook of Intensive Care and Emergency Medicine. Edited by Vincent JL. Berlin, Heidelberg, New York: Springer; 2009:728-737.

15. Billotta F, Giovannini F, Caramia R, Rosa G: Glycemia management in neurocritical care patients: a review. J Neurosurg Anesthesiol 2009, 21:2-9.

16. Oddo M, Schmidt JM, Carrera E, Badjatia N, Connolly ES, Presciutti M, Ostapkovich ND, Levine JM, Le Roux P, Mayer SA: Impact of tight glycemic control on cerebral glucose metabolism after severe brain injury: a microdialysis study. Crit Care Med 2008, 36:3233-3238.

17. Krinsley J, Preiser JC: Moving beyond tight glucose control to safe effective glucose control. Crit Care 2008, 12:149. 